\title{
EFEKTIVITAS CAREER DEVELOPMENT LEARNING PROGRAM UNTUK MENGEMBANGKAN EMPLOYABILITY PADA SISWA SMK
}

\author{
Rezki Ashriyana Sulistiobudi dan Lucia Voni Pebriani \\ Fakultas Psikologi, Universitas Padjadjaran, Bandung, Indonesia \\ E-mail: rezki.ashriyana@unpad.ac.id
}

\begin{abstract}
ABSTRAK, Sekolah vokasi diharapkan dapat menjadi salah satu alternatif untuk bisa membantu memangkas tingkat pengangguran di Indonesia. Program revitalisasi dan berbagai kebijakan yang dilakukan masih belum cukup signifikan untuk meningkatkan kemampuan kerja lulusan. Dalam konsep employability development, kemampuan kerja lulusan perlu dipersiapkan sejak dini dengan dasar penetapan arah karir yang matang. Melalui career development learning dengan tahapan dasar yaitu membangun self awareness dan opportunity awareness, maka disusunlah sebuah program yang terdiri dari berbagai aktivitas yang disebut Career Development Learning Program. Sebanyak 26 orang peserta yang berasal dari salah satu satu Sekolah Menengah Kejuruan (SMK) di Jatinangor berpartisipasi dalam program ini. Berdasarkan hasil analisa, terdapat peningkatan self awareness yang signifikan pada siswa. Pasca program, peserta juga mengalami peningkatan upaya dalam career self exploration untuk membangun opportunity awareness mengenai dunia kerja. Hal ini menjadi tahapan kritis untuk menentukan aktivitas-aktivitas relevan yang dapat berkontribusi pada pengembangan employability siswa selama dipersiapkan di jenjang sekolah.
\end{abstract}

Kata kunci: career development learning, self awareness, opportunity awareness, career exploration, employability, SMK

\section{EFECTIVITY OF CAREER DEVELOPMENT LEARNING PROGRAM IN DEVELOPING EMPLOYABILITY OF VOCATIONAL STUDENTS}

\begin{abstract}
Vocational schools are expected to be an alternative to reduced unemployment in Indonesia. Nowadays, the revitalization program and various policies are still not significant enough to improve graduates' work capabilities. In the concept of employability development, graduates' work abilities need to be prepared with the mature career direction. Through career development learning with the basic stages of building self-awareness and opportunity awareness, a program consists of various activities called the Career Development Learning Program. 26 participants from one of the Vocational Schools in Jatinangor participated in this program. Based on the results of the analysis, there is a significant increase in self-awareness of students. After the program, participants also experienced increased efforts in career self-exploration to build opportunity awareness about the world of work. This is a critical stage for determining relevant activities that can contribute to the development of student employability while being prepared at the school level.
\end{abstract}

Key words: career development learning, self-awareness, opportunity awareness, career exploration, employability, vocational school

\section{PENDAHULUAN}

Dengan adanya Instruksi Presiden Nomor 9 Tahun 2016 tentang Revitalisasi SMK dalam Rangka Peningkatan Kualitas dan Daya Saing Sumber Daya Manusia Indonesia, maka dimulailah era revitalisasi dan pengembangan kemampuan lulusan Sekolah Menengah Kejuruan (SMK). Kementrian Pendidikan dan Kebudayaan (Kemendikbud) telah menjalankan beberapa kebijakan untuk mengimplementasikan Revitalisasi SMK. Beberapa kebijakan tersebut antara lain membuat peta jalan pengembangan SMK; pengembangan dan penyelarasan kurikulum; kerja sama sekolah dengan dunia usaha, industri, serta perguruan tinggi; dan inovasi pemenuhan dan peningkatan profesionalitas guru dan tenaga kependidikan (Kementrian Pendidikan dan Kebudayaan, 2018). Berdasarkan data dari Badan Pusat Statistik, saat ini tingkat pengangguran SMK perlahan-lahan menunjukkan penurunan yang pada tahun 2017 sejumlah 9,27\% saat ini menjadi 8,92\% (Kementrian Pendidikan dan Kebudayaan, 2018). Hanya saja, hal ini memang masih kurang menggembirakan. Penurunan tingkat pengangguran belum cukup signifikan.

Salah satu aspek yang perlu diperhatikan adalah pendidikan SMK itu sendiri. Tidak meratanya standar kualitas pendidikan vokasi setara sekolah menengah atas atau dalam hal ini SMK, telah menjadi bahan diskusi selama beberapa tahun belakangan ini. Ditemukan bahwa variasi kualitas lulusan SMK pun memiliki rentang yang cukup lebar. Pada beberapa SMK unggulan di kota besar, mereka telah memiliki sistem kerjasama dan pembekalan yang memadai serta berdasar link \& match dengan kebutuhan industri. Hal yang dimaksud adalah setiap input yang diberikan kepada siswanya relevan dengan kebutuhan di industri. Namun, tidak sedikit pula yang masih dalam proses untuk dapat mempersiapkan pola tersebut di institusi masing-masing. Sementara itu, asupan diperlukan sebagai pengayaan bagi siswa calon lulusan sehingga para lulusan memperoleh tambahan program yang dapat membantu mereka dalam mempersiapkan diri memasuki dunia pekerjaan.

Program yang dilakukan diantaranya adalah mengintegrasikan soft skill ke dalam pembelajaran dan mengimplementasikan pendidikan berbasis kewirausahaan (Ramadhan \& Ramdani, 2013). Seluruh kompetensi tersebut dapat dikembangkan dengan baik, serta dapat memberikan hasil yang optimal manakala para siswa merasa bahwa apa yang ia lakukan sesuai 
dengan minat dan kemampuannya. Untuk para lulusan, langkah terbaik untuk bisa mengamankan pekerjaan yang mereka minati setelah lulus adalah melalui pendidikan dalam pengembangan karir atau yang biasa disebut career development learning (Pool \& Sewell, 2007).

Pengembangan karir meliputi aktivitas yang membantu siswa mengembangkan awareness diri, memungkinkan mereka untuk mempertimbangkan secara matang apa saja jenis pekerjaan yang mereka senangi, menarik bagi mereka, memotivasi mereka dan sesuai dengan karakteristik diri mereka (Law and Watts, 1977). Mereka juga akan belajar bagaimana menemukan pasar tenaga kerja dan melihat kesempatan yang tersedia bagi mereka, bagaimana menampilkan diri mereka secara efektif dan prospektif terhadap pemberi kerja dan bagaimana membuat keputusan mengenai karir yang akan mereka jalani.

Berdasarkan pemahaman tersebut, pengembangan karir tidak hanya membuat para siswa menjadi peduli tentang minat kerjanya tetapi juga sebagai landasan awal dibangunnya kemampuan kerja (employability). Menurut Rothwell, Jewell, \& Hardie (2009) bahwa employability adalah persepsi mengenai kemampuan diri untuk memperoleh dan mempertahankan pekerjaan yang sesuai dengan kualifikasi diri seseorang. Lebih jelas, employability juga dibahas dengan pendekatan Career EDGE Model yang dikembangkan oleh Pool \& Sewell (2007). Berdasarkan konsep tersebut, employability didefiniskan sebagai '....seperangkat keterampilan, pengetahuan, pemahaman dan karakteristik personal yang akan membuat seseorang akan lebih mudah bekerja dan mengamankan pekerjaan yang memuaskan dan membuat mereka sukses' (Pool \& Sewell, 2007). Oleh sebab itulah, pekerjaan yang memuaskan dan menyenangkan bagi mereka menjadi hal penting dan mendasar sehingga siswa lebih tergerak untuk mengembangkan diri mereka untuk menjadi lebih employable dan siap bekerja setelah lulus dari sekolah.

Career Development Learning dapat dilihat sebagai aspek dari employability atau sebagai sebuah rangkaian meta-skill yang saling terkait (Watts, 2014). Hal ini juga diperkuat oleh pendapat dari Knight \& Yorke (2004) yang menyatakan bahwa keterampilan dalam merencanakan karir menjadi salah satu dari 7 makna dari employability yang ia sampaikan. Career Development learning terdiri dari beberapa aspek yaitu:

1. Self awareness - misalnya pemahaman diri akan minat, kemampuan, value dsb.

2. Opportunity awareness - mengetahui kesempatan kerja, tantangan dan persyaratan apa yang dibutuhkan untuk setiap jenis pekerjaan.

3. Decision learning - keterampilan untuk memutuskan pekerjaan atau karir mana yang akan dipilih.

4. Transition learning - termasuk kemampuan dalam mencari lapangan pekerjaan dan keterampilan menampilkan dirinya di depan para pemberi kerja.
Melalui seluruh tahapan tersebut akan membuat siswa menjadi lebih matang dan siap dalam menghadapi masa setelah lulus sekolah. Kemudian, tahap lain yang sangat krusial bagi siswa tahun terakhir adalah membangun self awareness dan opportunity awareness. Hal ini menjadi dasar siswa untuk bisa membuat keputusan karir, menentukan apa pekerjaan dan profesi yang akan digeluti nantinya setelah lulus sekolah Hal ini sebagai dasar bagi mereka untuk dapat membuat keputusan karir dan memiliki kemampuan dalam memulai transisi dari masa sekolah ke dunia kerja. Untuk dapat memiliki opportunity awareness yang baik maka siswa perlu melakukan career exploration.

Career exploration dapat dipandang sebagai mekanisme adaptif dari individu untuk membangun adaptabilitas terhadap karir dan mengelolanya dalam kerangka pemilihan pekerjaannya (Hirschi, 2009; Savickas, 2002, 2013). Hal senada juga diungkapkan oleh Flum \& Blustein (2000) yang menyatakan bahwa career exploration adalah suatu proses yang meliputi eksplorasi dan evaluasi internal atribut, kesempatan eksternal dan kendala yang mungkin muncul terkait karir yang akan dijalani.

Oleh sebab itu maka pertanyaan penelitian dalam studi ini adalah:

1. Apakah terdapat peningkatan self awareness antara sebelum dan setelah dilakukannya career development learning program?

2. Apakah terdapat peningkatan perilaku career self exploration sebagai upaya membangun opportunity awareness, antara sebelum dan setelah dilakukannya career development learning program?

\section{METODE}

\section{Peserta dan Lokasi}

Peserta dalam kegiatan ini merupakan siswa tahun terakhir di salah satu SMK di Kecamatan Jatinangor, Sumedang. Persyaratan administrasi dan izin kepada pengelola sekolah diperoleh oleh peneliti sebelum kegiatan ini dilakukan. Peserta yang terlibat telah dijelaskan mengenai gambaran umum kegiatan dan dimintai kesediaannya terlebih dahulu melalui informed consent. Terdapat 27 orang siswa yang dipilih secara acak oleh sekolah untuk mengikuti program, terdiri dari 20 perempuan dan 7 laki-laki. Dari 27 orang yang hadir, hanya 26 data yang digunakan karena 1 data tidak lengkap sehingga tidak digunakan dalam perhitungan kuantitatif.

\section{Prosedur Program}

Kegiatan ini didesain dengan konsep pelatihan, dilakukan dalam 1 hari kegiatan. Tahapan kegiatan yang dilakukan yaitu:

1. Pembentukan good rapport. Pada tahap ini kegiatan berisi perkenalan tim dengan seluruh peserta agar suasana dapat lebih cair. Aktivitas ini dilakukan dengan games sederhana dalam kelas besar yang di- 
arahkan untuk bisa membuat peserta lebih nyaman dan memecah kebekuan diantara para peserta.

2. Group Counselling. Sebelum group counselling dilakukan, peserta diberikan pretes mengenai career development learning dan self exploration. Setelah itu, peserta dibagi kedalam kelompok-kelompok kecil yang terdiri dari 5-8 orang. Setiap kelompok difasilitasi oleh seorang psikolog. Tujuan dalam group counselling ini diantaranya yaitu :

a. Siswa mengetahui kekuatan dan kelemahan diri

b. Siswa mengetahui minat diri

c. Siswa mengetahui rencana apa yang akan dilakukan setelah lulus sekolah

d. Siswa mengetahui apa saja opportunity dan threats yang mungkin muncul atas pilihan-pilihan aktivitas (rencana) setelah lulus sekolah Tahapan-tahapan dalam konseling kelompok mengikuti panduan dari Capuzzi \& Gross (2002) khususnya untuk career group counselling yaitu self awareness, self assesment, skill assesment, strength bombardment, career exploration, decision making, goal setting, job hunting dan reinforcing action plan. Sedianya seluruh tahapan ini dilakukan sehingga memerlukan waktu 7 kali pertemuan dan 1 kali sesi individual. Namun demikian, sesuai dengan tujuan yang disasar maka tahapan yang dilakukan dibatasi yaitu mulai dari self awareness hingga career exploration saja. Setiap psikolog dalam kelompok diberikan panduan yang terstandar mengenai tujuan konseling, alur dan alternatif pertanyaan yang dapat diajukan untuk menggali poin-poin sesuai dengan tujuan.

3. Pemaparan materi mengenai pengembangan kemampuan kesiapan kerja SMK. Materi disampaikan secara lecturing selama 30 menit dan diakhiri dengan sesi diskusi serta tanya jawab. Pada sesi ini peserta dipaparkan mengenai tantangan kerja lulusan SMK, dasar kompetensi, bidang kerja yang mungkin digeluti di setiap jurusan, kesenjangan dunia industri dan dunia kerja, langkah pengembangan kompetensi yang dapat dilakukan secara mandiri, sumber-sumber informasi rekruter ataupun balai latihan kerja.

4. Simulasi. Aktivitas ini juga dilakukan dalam kelompok dengan pendekatan experiential learning (Kolb, 1984). Metode ini bertujuan agar peserta pelatihan memperoleh pembelajaran melalui pengalaman khususnya melalui metode simulasi (roleplay). Peserta diberikan situasi dimana ia merupakan lulusan SMK dan dihadapkan pada pilihan untuk melanjutkan sekolah dan juga bekerja. Peserta diminta untuk menuliskan profil dirinya dan mempresentasikan di hadapan rekan-rekan yang berperan sebagai penilai. Peserta lain diminta memberikan pendapatnya mengenai apa saja yang menonjol sebagai kemampuan dan juga apa yang masih harus dikembangkan. Hal ini kemudian didiskusikan dan disampaikan secara terbuka di dalam kelompok. Peserta kemudian diminta untuk mengisi action plan atau rencana tindakan yang akan dilakukan dalam jangka waktu 2 minggu kedepan berdasarkan aspek pengembangan yang sudah ia peroleh ketika konseling kelompok dan juga insight selama melakukan simulasi (roleplay).

5. Evaluasi. Sebelum kegiatan berakhir, peserta diberikan lembar postes yang terdiri dari career development learning dan self exploration. Peserta juga diingatkan untuk melakukan apa-apa saja yang sudah dituliskan dalam action plan dalam 2 minggu mendatang dan evaluasi perubahan perilaku akan dilakukan kemudian. Setelah 2 minggu, peneliti kembali mengumpulkan peserta untuk menguji peningkatan perilaku berdasarkan hasil action plan yang sudah diupayakan oleh masing-masing peserta.

\begin{abstract}
Alat Ukur
Untuk menguji efektivitas program career development learning dilakukan pengujian melalui beberapa tahap berdasarkan pendekatan dari Kirkpatrick (1977), yang terdiri dari 3 kegiatan. Tahap pertama, mengevaluasi reaksi peserta yang diukur melalui kuesioner tentang tanggapan peserta mengenai pelaksanaan kegiatan yang terdiri dari: kesesuaian tujuan dengan materi dan metode, fasilitator dan fasilitas kegiatan. Contoh item dalam alat ukur ini misalnya "Fasilitator menguasai materi dengan baik". Alat ukur ini di desain secara mandiri oleh peneliti, divalidasi melalui pengecekan konten oleh 3 orang expert dan menghasilkan koefisien reliabilitas sebesar 0,702.

Tahap kedua, mengukur peningkatan self awareness peserta. Alat ukur yang digunakan adalah salah satu sub-aspek dalam Career EDGE Employability Development Profile (Pool, Qualter, \& Sewell, 2014) yaitu career development learning. Aspek ini terdiri dari 6 item yang menggambarkan mengenai kondisi siswa terkait pengetahuannya tentang rencana pengembangan karir dirinya. Salah satu item dalam alat ukur ini misalnya "Saya mengetahui dimana dapat menemukan informasi tentang pekerjaan yang saya minati”. Skala yang digunakan adalah Likert 1 - 6 mulai dari 'Tidak Mengetahui' sampai dengan 'Mengetahui'. Alat ukur ini telah diadaptasi dari aslinya dan menghasilkan koefisien reliabilitas 0,757. Alat ukur ini diberikan 2 kali sebagai pre-test dan post-test, pada saat sebelum dilakukannya kegiatan dan segera setelah kegiatan selesai dilakukan.

Tahap ketiga, mengukur peningkatan perilaku career self exploration untuk membangun opportunity awareness. Alat ukur ini diberikan sebelum kegiatan berlangsung, segera setelah kegiatan selesai (post-test 1) dan 2 minggu setelah kegiatan dilaksanakan (post-test 2). Peneliti mengambil 1 aspek self exploration dalam alat ukur career engagement yang dikembangkan oleh Hirschi, A., Freund, P. A., \& Herrmann, A. (2014).
\end{abstract}


Alat ukur menggunakan skala Likert dengan rentang 1-6 mulai dari 'Tidak Pernah' sampai 'Sangat Sering Dilakukan'. Contoh item dalam alat ukur ini misalnya "Untuk mengembangkan karier, saya mengumpulkan informasi mengenai nilai-nilai dalam diri yang saya miliki. Alat ukur ini diadaptasi terlebih dahulu oleh peneliti dan menghasilkan koefisien reliabilitas sebesar 0,853 .

\section{Analisa Data}

Data mengenai reaksi peserta kegiatan diolah menggunakan statistik deskriptif yang meliputi nilai rerata dan disajikan dalam diagram batang. Data mengenai peningkatan pengetahuan tentang career development learning antara sebelum dan setelah dilakukannya kegiatan, perubahan perilaku mengenai self exploration diuji menggunakan Statistika non parametrik yaitu Wilcoxon Signed Rank Test di SPSS 23. Statistika non parametrik digunakan karena jumlah sampel yang relatif sedikit yaitu hanya sebanyak 25 orang. Pengujian hipotesis menggunakan nilai signifikansi 0,05 yang mengindikasikan ada atau tidaknya perbedaan antara sebelum pelatihan dan sesudah pelatihan.

\section{HASIL DAN PEMBAHASAN}

Berdasarkan hasil evaluasi reaksi (Gambar 1 dan 2), peserta memberikan respon yang memuaskan pada setiap aspek. Semua nilai berada diatas 3 dari rentang 1-4 skala. Hal ini berarti peserta merasa puas akan apa yang diperolehnya ketika pelaksanaan kegiatan. Materi sesuai dengan apa yang mereka butuhkan, alat bantu dan tools lainnya memadai, fasilitator membantu dengan cukup efektif proses dalam setiap kegiatan seperti konseling, pendampingan kelompok maupun ketika memberikan materi didalam kelas. Aspek yang paling dinilai baik oleh mereka adalah metode. Dengan beragam metode yang dilakukan dalam kegiatan ini maka peserta tidak merasa bosan, selalu antusias dan mendapat pengalaman yang tidak hanya bermanfaat tetapi juga menyenangkan bagi mereka.

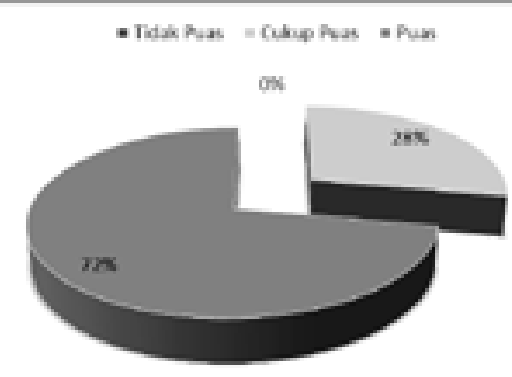

Gambar 1. Tingkat Kepuasan Peserta terhadap Kegiatan

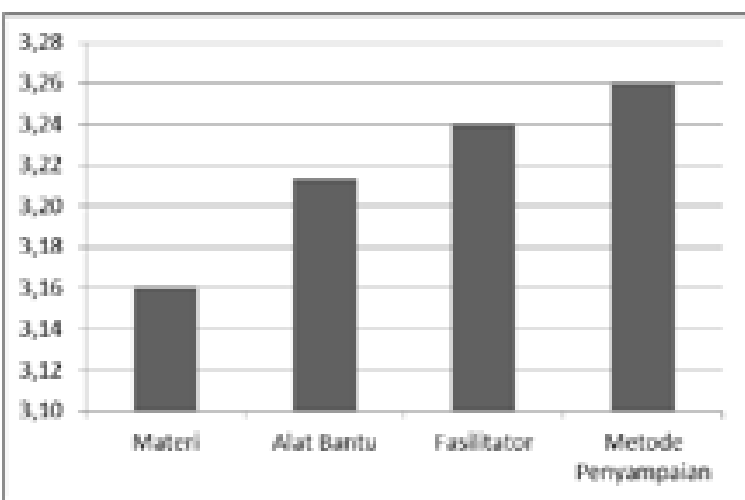

Gambar 2. Perbandingan Rerata Indikator Evaluasi Reaksi

Berdasarkan Tabel 1 dapat dilihat bahwa self awareness peserta menunjukkan perbedaan yang cukup besar antara sebelum dan setelah kegiatan. Mereka merasa lebih mengetahui mengenai kekuatan dan aspek pengembangan diri mereka melalui program ini. Selain peningkatan mengenai pengetahuan, perubahan perilaku juga dirasakan oleh peserta cukup besar antara sebelum dan 2 minggu setelah pelatihan. Perbedaan skor terutama pada post-test 1 (segera setelah kegiatan selesai) dan post-test 2 (setelah 2 minggu pasca pelatihan). Selama 2 minggu tersebut mereka diminta untuk merealisasikan action plan yang sudah dibuat sebelumnya.

Tabel 1. Hasil Statistika Deskriptif Pre-Test dan Post-Test

\begin{tabular}{lccr}
\hline & Mean & Min. & Maks. \\
\hline $\begin{array}{l}\text { Pretest Self } \\
\text { Awareness }\end{array}$ & 2,916 & 1,83 & 4,83 \\
$\begin{array}{l}\text { Postest Self } \\
\text { Awareness }\end{array}$ & 3,628 & 2,67 & 5,33 \\
$\begin{array}{l}\text { Pretest } \\
\text { Career Self }\end{array}$ & 2,923 & 1,38 & 5,00 \\
$\begin{array}{l}\text { Exploration } \\
\text { Postest 1 }\end{array}$ & & & \\
$\begin{array}{l}\text { Career Self } \\
\text { Exploration }\end{array}$ & 3,062 & 1,88 & 4,75 \\
$\begin{array}{l}\text { Postest 2 } \\
\text { Career Self } \\
\text { Exploration }\end{array}$ & & & \\
\hline
\end{tabular}

Pada Tabel 2, dapat dikatakan bahwa adanya peningkatan self awareness antara sebelum dan setelah kegiatan dirasakan oleh sekitar $\mathrm{N}=20$ orang. Sedangkan pada pengukuran perubahan perilaku antara sebelum dan segera setelah dilakukannya pelatihan menunjukkan perbedaan yang cukup berimbang antara pre-test dan posttest. Hal ini disebabkan karena peserta masih belum mengaktualisasikan perubahan perilaku pada saat tersebut. Perbedaan terbesar ada pada postest 1 dan postest 2 yaitu sebanyak 24 orang yang mempersepsi adanya peningkatan perilaku dalam career self exploration berdasarkan action plan yang mereka susun sebelumnya.

Tabel 2. Hasil Perbandingan Hitung Nilai Pretest dan Postests

\begin{tabular}{lcrrr}
\hline & N & Mean Rank & Sum of Rank \\
\hline $\begin{array}{l}\text { Pretest- } \\
\text { Postest }\end{array}$ & $\begin{array}{c}\text { Negative } \\
\text { Ranks }\end{array}$ & 5 & 6,60 & 33,00
\end{tabular}




\begin{tabular}{|c|c|c|c|c|}
\hline & & $\mathrm{N}$ & Mean Rank & Sum of Rank \\
\hline \multirow[t]{3}{*}{$\begin{array}{l}\text { Self } \\
\text { Awareness }\end{array}$} & $\begin{array}{l}\text { Positive } \\
\text { Ranks }\end{array}$ & 20 & 14,60 & 292,00 \\
\hline & Ties & 1 & & \\
\hline & Total & 26 & & \\
\hline $\begin{array}{l}\text { Pretest- } \\
\text { Postest }\end{array}$ & $\begin{array}{l}\text { Negative } \\
\text { Ranks }\end{array}$ & 11 & 11,82 & 130,00 \\
\hline \multirow[t]{3}{*}{$\begin{array}{l}\text { Career Self } \\
\text { Exploration }\end{array}$} & $\begin{array}{l}\text { Positive } \\
\text { Ranks }\end{array}$ & 13 & 13,08 & 170,00 \\
\hline & Ties & 2 & & \\
\hline & Total & 26 & & \\
\hline Postest 1-2 & $\begin{array}{l}\text { Negative } \\
\text { Ranks }\end{array}$ & 0 & ,00 & ,00 \\
\hline \multirow[t]{3}{*}{$\begin{array}{l}\text { Career Self } \\
\text { Exploration }\end{array}$} & $\begin{array}{l}\text { Positive } \\
\text { Ranks }\end{array}$ & 24 & 12,50 & 300,00 \\
\hline & Ties & 2 & & \\
\hline & Total & 26 & & \\
\hline
\end{tabular}

Hasil uji non parametrik statistik menggunakan Wilcoxon Rank Signed Test menunjukkan hasil bahwa terdapat peningkatan yang signifikan mengenai self awareness peserta antara sebelum dan setelah kegiatan. Selain itu, siswa juga mengalami peningkatan upaya dalam menggali tentang minat karir yang lebih tinggi setelah kegiatan dilakukan khususnya ketika action plan dijalankan oleh mereka.

Tabel 3. Nilai Uji Signfikansi Peningkatan Self Awareness dan Career Self Exploration

\begin{tabular}{lcr}
\hline & $\mathrm{Z}$ & $\begin{array}{c}\text { Asymp. Sig. } \\
\text { (2-tailed) }\end{array}$ \\
\hline $\begin{array}{l}\text { Pretest }- \text { Postest } \\
\text { Self Awareness }\end{array}$ & $-3,487$ &, $000^{* *}$ \\
Pretest - Postest & & \\
Career Self &, 567 \\
Exploration &,- 572 & \\
Postest $1-$ Postest 2 & &, $000^{* *}$ \\
Career Self & & \\
Exploration & $-4,369$ & \\
\hline${ }^{*} \mathrm{p}<0,001$ & & \\
\hline
\end{tabular}

Respon peserta terhadap kegiatan ini secara umum positif. Hal ini merupakan hal yang mendasar, jika peserta secara umum puas dengan program yang diberikan maka kecenderungan untuk memunculkan hasil yang positif pada tujuan kegiatan akan lebih besar. Berdasarkan data, peserta lebih puas akan dimensi metode. Hal ini berarti peserta merasa tidak bosan dengan adanya variasi metode yang digunakan dalam kegiatan ini mulai dari ceramah, konseling kelompok, simulasi dan diskusi. Hal ini membangun keaktifan peserta dalam kegiatan dan membuat mereka merasa lebih yakin dalam menampilkan diri mereka.

Berdasarkan hasil penelitian ditemukan bahwa melalui program career development learning, peserta merasakan adanya peningkatan self awareness. Dengan begitu dapat dikatakan bahwa ia lebih mampu mengidentifikasi pengetahuan, kemampuan dan keterampilan yang dimiliki setelah lulus dari sekolah, mengidentifikasi keterampilan personal, mengidentifikasi minat, nilai dan kepribadian dalam konteks pekerjaan, mengidentifikasi kekuatan dan kelemahan diri serta area yang memerlukan pengembangan lebih lanjut. Hal ini adalah kesempatan awal yang penting bagi siswa sehingga dapat membantu siswa untuk bisa lebih memahami dirinya, memberikan pertimbangan nyata bagi mereka untuk dapat menikmati pekerjaan yang nantinya mereka geluti, pekerjaan yang sesuai dengan karakteristik kepribadian mereka, membantu mereka untuk lebih menyenangi pekerjaan yang juga dapat memotivasi mereka (Pool \& Sewell, 2007).

Ketika para siswa sudah paham mengenai dirinya sendiri, maka kemudian peserta diarahkan untuk bisa memetakan alternatif kesempatan pekerjaan yang memungkinkan bagi dirinya. Melalui opportunity awareness ini, peserta dapat menunjukkan pengetahuan mengenai kecenderungan pekerjaan yang dapat dimasuki oleh para lulusan SMK, memahami persyaratan yang diminta oleh para pemberi kerja dan memahami pengetahuan mengenai karir terkait dan pekerjaan apa saja yang diminati (Watts, 2014). Untuk dapat memiliki opportunity awareness yang memadai, maka siswa harus terlebih dahulu melakukan career exploration sebagai upaya untuk bisa memahami dunia kerja dan pekerjaan yang sekira sesuai dengan dirinya. Berdasarkan hasil studi ini, ditemukan bahwa program ini efektif untuk mendorong siswa melakukan eksplorasi karir yang sesuai bagi dirinya. Melalui action plan yang telah dibuat sebelumnya, siswa berkomitmen untuk dapat mengaktualisasikan action plan tersebut menjadi upaya-upaya nyata yang mendorong terbangunnya opportunity awareness.

Career exploration ini merupakan tahapan yang kritis dalam perkembangan karir individu. Hal ini lebih banyak dilakukan selama masa remaja dan atau dewasa awal (Super, 1957). Hal ini sejalan dengan fenomena yang diambil pada siswa SMK yang pada saat terlibat dalam program ini berusia 16-18 tahun. Duchesne et al. (2012) menemukan juga bahwa siswa yang lebih aktif melakukan eksplorasi karir cenderung lebih berorientasi pada prestasi dan target tertentu dalam kehidupannya. Hal ini berarti mereka akan lebih yakin dalam menetapkan tujuan kerja dan melakukan upaya-upaya pengembangan diri yang jelas dapat berkontribusi bagi kesiapan kerjanya. Semakin mereka mantap dalam menentukan arah karir, maka akan semakin mantap pula pengembangan employability yang akan mereka lakukan.

Sebagai satu kesatuan dalam career development learning, hal ini dapat dilihat sebagai serangkaian meta-skill yang dapat menjadi dasar dari pengembangan employability bagi para lulusan (Watts, 2014). Didasari dengan career development learning yang memadai, maka employability yang diharapkan adalah kemampuan yang 'bertahan' atau sustainable employability. Hal ini berarti tidak hanya mengamankan pekerjaan pertama tetapi juga tetap employable selama hidup. Se- 
bagaimana disampaikan oleh Knight \& Yorke (2004), employability tidak hanya saat pekerjaan pertama diperoleh, tetapi secara konstan dapat diperbaharui dan mampu bertahan. Hal ini tidak hanya terkait dengan atribut yang diperlukan untuk bisa sukses dalam pekerjaan tertentu, tetapi juga atribut yang diperlukan untuk mengelola pengembangan karir seseorang yang akan mengarah pada sustainable employability.

Adapun limitasi dari penelitian ini adalah sedikitnya jumlah responden yang mengikuti kegiatan juga tidak adanya kelompok kontrol sebagai pembanding sehingga dikhawatirkan masih terjadi bias hasil. Untuk penelitian kedepannya maka dapat dilakukan dengan responden lebih banyak dan menggunakan kelompok kontrol dalam desain penelitian. Selain itu, untuk dapat membuktikan aplikasi career development learning secara utuh maka program ini dapat dilakukan kembali dengan memasukkan pengembangan career decision making skill dan juga transition learning. Menurut Watts (2014) untuk career decision making skill maka aspek yang dapat dibahas mengenai elemen kunci dari pembuatan keputusan dalam konteks perencanaan karir, evaluasi prioritas personal yang berdampak pada pilihan karir di masa depan, rencana pengembangan karir jangka pendek dan menengah, identifikasi langkah untuk bisa mengambil kesempatan dalam pengembangan karir dan review perubahan rencana dan ide mengenai pekerjaan. Untuk transition learning, aspek yang dapat dibahas diantaranya memahami strategi dalam mencari pekerjaan sesuai dengan kesempatan yang tersedia, memahami metode seleksi atau rekrutmen yang nantinya akan dihadapi, kemampuan untuk bisa mengakses berbagai peluang kerja, kemampuan untuk bisa menampilkan diri dengan baik pada saat interview atau bertemu dengan pemberi kerja.

\section{SIMPULAN}

Mempersiapkan lulusan SMK untuk bekerja merupakan proses panjang yang memerlukan tahapan-tahapan secara sistematis dan terencana. Self awareness dan career self exploration yang merupakan elemen dasar dari career development merupakan tonggak awal dipetakannya aktivitas-aktivitas yang mendorong pengembangan employability dari siswa. Program career development learning yang dikembangkan melalui berbagai aktivitas seperti konseling kelompok, simulasi, diskusi dan juga paparan mengenai tantangan dunia kerja terbukti efektif untuk meningkatkan self awareness dan meningkatkan upaya career self exploration pada siswa. Motivasi dan komitmen siswa dalam menjalankan program ini juga menjadi hal yang penting karena akan mempengaruhi bagaimana setiap tugas termasuk action plan dijalankan dengan baik oleh mereka. Secara praktis, maka sebaiknya program career development learning sudah dipersiapkan sejak awal siswa mulai memasuki jenjang SMK sehingga akan lebih memantapkan pilihan aktivitas dalam tahapan-taha- pan pengembangan employability selanjutnya. Pihak sekolah dapat bekerja sama dengan para ahli di bidang employability ataupun pengembangan karir sehingga persiapannya dapat lebih matang dan terencana. Aktivitas pengembannya pun dapat disesuaikan dan diperkaya pada dalam program yang telah dimiliki oleh sekolah.

\section{DAFTAR PUSTAKA}

Capuzzi, D. E., \& Gross, D. R. (2002). Introduction to group counseling. Love Publishing Company.

Duchesne, S., Mercier, A., \& Ratelle, C. F. (2012). Vocational exploration in middle school: Motivational characteristics of students and perceptions of the learning climate/exploration vocationnelle au début du secondaire: Caractéristiques motivationnelles des élèves et perceptions du climat d'apprentissage. Canadian Journal of Counselling and Psychotherapy (Online), 46(4), 367-386.

Flum, H., \& Blustein, D. L. (2000). Reinvigorating the study of vocational exploration: A framework for research. Journal of Vocational Behavior, 56(3), 380-404. doi: 10.1006/jvbe.2000.1721

Hirschi, A. (2009). Career adaptability development in adolescence: Multiple predictors and effect on sense of power and life satisfaction. Journal of Vocational Behavior, 74(2), 145-155.

Hirschi, A., Freund, P. A., \& Herrmann, A. (2014). The career engagement scale: Development and validation of a measure of proactive career behaviors. Journal of Career Assessment, 22(4), 575-594.

Kementrian Pendidikan dan Kebudayaan. (2018). Angka Partisipasi Kerja Lulusan SMK Terus Meningkat. Retrieved November 13, 2018, from https: //www. kemdikbud.go.id/main/blog/2018/11/angkapartisipasi-kerja-lulusan-smk -terus-meningkat

Kirkpatrick, D. L. (1977). Evaluating training programs: Evidence vs. proof. Training Dev J.

Knight, P., \& Yorke, M. (2004). Learning, curriculum and employability in higher education. Psychology Press.

Law, B. \& Watts, A.G. (1977). Schools, Careers and Community. London: Church Information Office

Pool, L. D., \& Sewell, P. (2007). The key to employability: Developing a practical model of graduate employability. Education and Training, 49(4), 277289. https: //doi.org/10.1108/00400910710754435

Pool, L. D., Qualter, P., \& Sewell, P. J. (2014). Exploring the factor structure of the CareerEDGE employability development profile. Education and Training, 56(4), 303-313. https://doi.org/10.1108/ ET-01-2013-0009

Ramadhan, M. A., \& Ramdani, S. D. (2013). Vocational Education Perspective on Curriculum 2013 and Its Role in Indonesia Economic Development, (May 2014), 122-130. Retrieved from http:// eprints.uny.ac.id/24449/ 